\title{
Paleoseismology of silent faults in the Central Apennines (Italy): the Mt. Vettore and Laga Mts. faults
}

\author{
Fabrizio Galadini $\left({ }^{1}\right)$ and Paolo Galli $\left({ }^{2}\right)$ \\ ( $\left.{ }^{1}\right)$ Istituto di Geologia Ambientale e Geoingegneria, CNR, Roma, Italy \\ $\left(^{2}\right)$ Servizio Sismico Nazionale, DPC, Roma, Italy
}

\begin{abstract}
Paleoseismological analyses have been performed in the Central Apennines along faults showing geomorphological evidence of Late Quaternary activity and characterised by the absence of historical seismicity. Three trenches were made along the Mt. Vettore Fault, across a scarp on a Late Pleistocene-Holocene alluvial fan. The youngest displacement event (E1) occurred after 4155-3965 years BP and before the 6th-7th century A.D., a previous event (E2) occurred between 5940-5890/5795-5780 years BP and 4155-3965 years BP, while the oldest event (E3) occurred between 18000-12000 years BP and 5940-5890/5795-5780 years BP. One trench was excavated across the Laga Mts. Fault which gave evidence for two displacement events after 8320-8150 years BP. The minimum vertical slip rate estimated through the paleoseismological analysis of the Mt. Vettore Fault is $0.11-0.36 \mathrm{~mm} / \mathrm{yr}$, while the minimum slip rate along the Laga Mts. Fault is $0.12 \mathrm{~mm} / \mathrm{yr}$. The paleoseismologically inferred recurrence interval is not longer than 4690 years for the Mt. Vettore Fault and not longer than 7570 years for the Laga Mts. Fault, while the minimum elapsed times since the last activation are 1300 and 800 years for the two faults, respectively. The evaluation of the former elapsed time was based on paleoseismological data, while the estimation of the latter was based on the absence of historical earthquakes which may have been caused by the Laga Mts. Fault and on the completeness of the historical catalogues for the large magnitude events in the last eight centuries. Based on the length of the fault at the surface, earthquakes with $M 6.5$ and 6.6 may be expected from the activation of the Mt. Vettore and Laga Mts. faults, respectively.
\end{abstract}

Key words paleoseismology - active fault - Holocene - Central Italy

\section{Introduction}

Recent works summarising data on the geometry and the kinematics of the active faults show that the Central Apennines are affected by two parallel active fault sets characterised by predominantly normal movements (Barchi et al.,

Mailing address: Dr. Fabrizio Galadini, Istituto di Geologia Ambientale e Geoingegneria, Area della Ricerca di Roma «Tor Vergata», Via del Fosso del Cavaliere 100, 00133 Roma, Italy; e-mail: f.galadini@igag.cnr.it
2000; Galadini and Galli, 2000). The identification of the active faults mainly followed geomorphologic criteria and paleoseismological data are available for few faults only (i.e. the Campo Imperatore Fault, Giraudi and Frezzotti, 1995; the Aremogna-Cinquemiglia Fault, D'Addezio et al., 2001; the Ovindoli-Pezza Fault, Pantosti et al., 1996; the Fucino Fault, Galadini and Galli, 1999).

A comparison between the active faulting framework and the distribution of the seismicity, as derived from the available historical seismic catalogues (e.g., Working Group CPTI, 1999; reporting earthquakes since 217 B.C.), indicates that earthquakes with $M \geq 6.5$ can be related to the westernmost fault set. Paleoseismological data on the Ovindoli-Pezza Fault (which is part of this 
fault set) suggest that also this fault activated during the historical period (the youngest event has been radiocarbon dated at the Middle Ages; Pantosti et al., 1996). On the other hand, the active faults of the eastern set show geomorphic evidence of past activation related to strong earthquakes, but no significant historical earthquakes may be related to them (Galadini and Galli, 2000). For this reason we usually define these faults as «silent».

The silent state of the eastern faults suggested to adopt a paleoseismological approach to investigate two faults of this set which display clear evidence of recent movements, i.e. the Mt. Vettore and the Laga Mts. faults. Investigations through the excavation of trenches were made during 1998 and 1999.

The following sections will be dedicated to the recognition of the paleoseismologically inferred displacement events. Tectonic data are supported by the stratigraphic analysis related to the sedimentary units detected in the trenches. Further sections will be dedicated to the definition of the parameters describing the fault behaviour (slip rate, recurrence interval, elapsed time since the last activation, maximum expected magnitude).

\section{Seismotectonic framework}

The Apennine Chain is affected by active normal faulting (Galadini et al., 2001 and references therein). Moderate-to-large-magnitude earthquakes reported in the available catalogues (e.g., Working Group CPTI, 1999) define a seismically active belt in the inner portion of the Apennine Chain, following the Apennine axis.

Active faulting has been documented for the Abruzzi sector of the Central Apennines (e.g., Barchi et al., 2000; Galadini and Galli, 2000; Valensise and Pantosti, 2001; Roberts et al., 2002). Some works define two main parallel sets of prevalently normal-to-oblique faults (Barchi et al., 2000; Galadini and Galli, 2000; D'Addezio et al., 2001; Valensise and Pantosti, 2001). In contrast, the works by Ghisetti and Vezzani (2000) and Roberts et al. (2002), mainly dedicated to structural aspects, define a larger number of active normal faults. Other works at a regional scale report active fault sets made of master faults showing strike-slip movements and shorter faults characterised by normal movements with a style typical of the strike-slip tectonics (Cello et al., 1997). All the available literature indicates, however, that the main active faults of the Central Apennines are located along the borders of intermontane extensional basins, they are several tens of kilometers long and have been responsible for some of the strongest earthquakes which occurred in peninsular Italy in the last few centuries (e.g., Barchi et al., 2000; Galadini and Galli, 2000; Valensise and Pantosti, 2001). Taking into account that: 1) the evidence of recent tectonic activity along some of the faults described by Ghisetti and Vezzani (2000) and Roberts et al. (2002) appears debatable (e.g., compare the Avezzano-Bussi Fault in the former work and the Salto Valley Fault in the latter with the data reported in Galadini and Messina, 2001), and 2) the role of strike-slip movements in the Central Apennines seems definitely secondary (as indicated by the great number of works available on the recent faulting of the Apennines: see the literature mentioned in Galadini et al., 2001 and Valensise and Pantosti 2001) we decided to adopt the more widely accepted structural scheme (fig. 1) for the active tectonic regime (Barchi et al., 2000; Galadini and Galli, 2000).

The Apennine sector reported in fig. 1 has been affected by several earthquakes with $M>6.5$. In particular, the catalogue by Working Group CPTI (1999, from which all the magnitude values and the epicentral locations have been taken) reports the 1349, 1456, 1703 (January 14), 1703 (February 2), 1706, 1915 events as the strongest earthquakes in the investigated region.

Galadini and Galli (2000) gathered all the available information on active faulting and paleoseismology of the region. Data show that the recurrence interval for surface faulting events in the Central Apennines is always longer than 1000 years and usually plurimillennial. Slip rates are lower than $1 \mathrm{~mm} / \mathrm{yr}$ and the length of the active faults ranges between 16 and more than $30 \mathrm{~km}$.

Galadini and Galli (2000) compared the data on the active faults with the long-term seismicity; this procedure gave rise to the hypothesis that almost the entire westernmost set of normal faults experienced activation after 1000 A.D. 


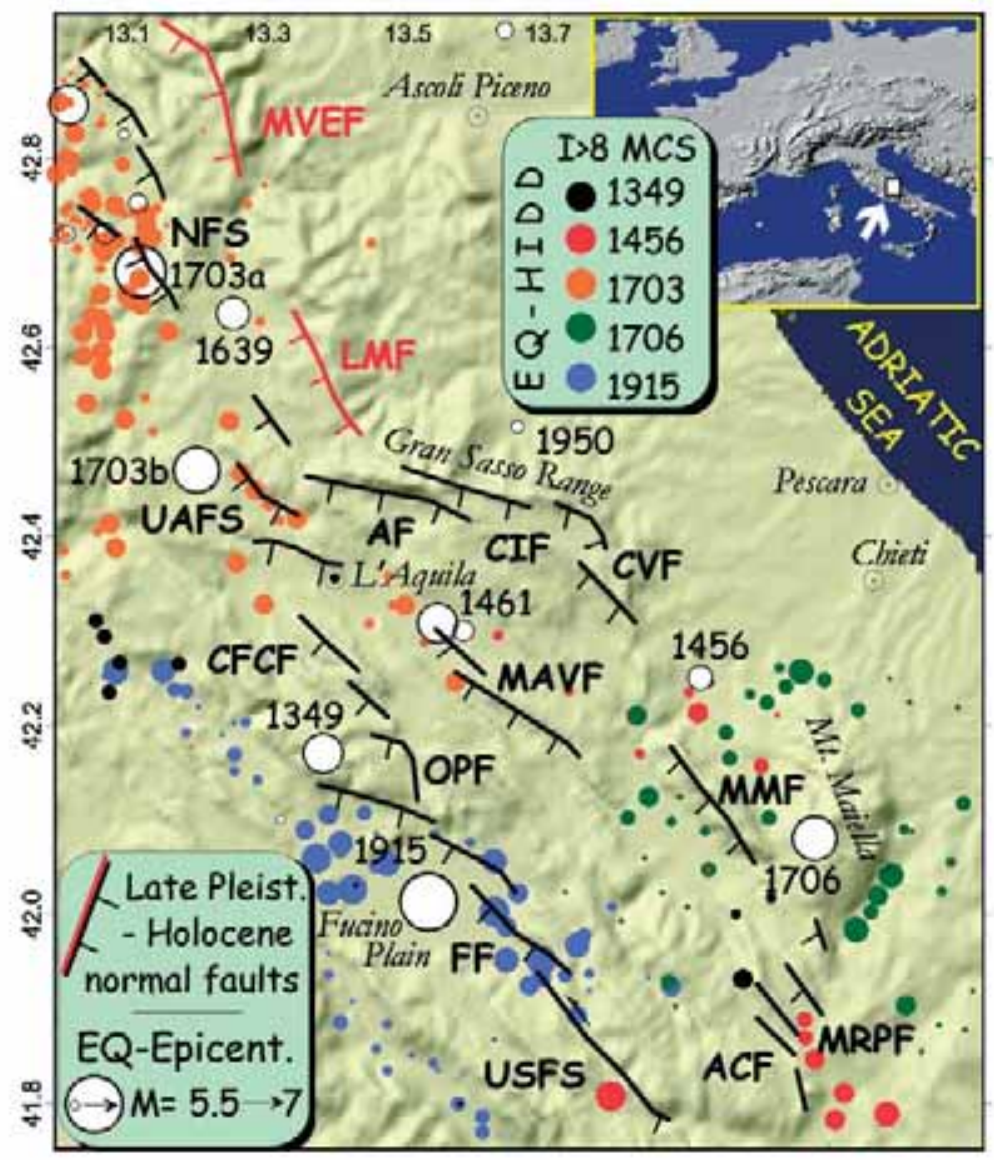

Fig. 1. Seismotectonic framework of the investigated area. The investigated faults are reported in red. Earthquake epicenters and the highest intensity datapoints distribution (HIDD; size proportional to intensity, $I>8$ MCS) were taken from Magri and Molin (1984) for the 1456 earthquake, Boschi et al. (1995) for the 1349 and 1706 earthquakes, Monachesi and Stucchi (1998) for the 1703 earthquake, Molin et al. (1999) for the 1915 earthquake; all the epicenter locations were derived from Working Group CPTI (1999). MVEF - Mt. Vettore Fault; NFS - Norcia Fault System; LMF - Laga Mts. Fault; UAFS - Upper Aterno Valley Fault System; AF - Assergi Fault; CIF - Campo Imperatore Fault; CVF - Mt. Cappucciata-Mt. San Vito Fault; CFCF - Campo Felice-Colle Cerasitto Fault; MAVF - Middle Aterno Valley Fault; OPF - Ovindoli-Pezza Fault; MMF - Mt. Morrone Fault; FF - Fucino Fault; MRPF - Mt. RotellaMt. Pizzalto Fault; ACF - Aremogna-Cinquemiglia Fault; USFS - Upper Sangro Valley Fault System.

(only the Sangro Valley Fault seems to be silent) while, in contrast, the available seismic catalogues do not indicate the occurrence of large earthquakes which may be consistent with the activation of faults of the easternmost set. The Mt. Vettore and Laga Mts. faults are part of this set of silent faults.

\section{Paleoseismological analysis}

The main purpose of our work was the definition of the chronology of the fault activity and the characteristics of the displacements (amount of offset, type of movement, ...). The chronological aim conditioned the choice of the 
Table I. Radiocarbon dates of samples collected in the investigated areas and in the trenches excavated across the Mt. Vettore and Laga Mts. faults. R - radiometric technique; BLC - bulk/low carbon material procedure; AMS - accelerator mass spectrometry technique.

\begin{tabular}{|c|c|c|c|c|c|c|c|c|}
\hline Sample & $\begin{array}{c}\text { Lab. code } \\
\text { Beta }\end{array}$ & Analysis & $\begin{array}{c}\mathrm{C}^{13} / \mathrm{C}^{12} \\
\text { ratio }\end{array}$ & $\begin{array}{l}\text { Measured } \\
\text { age BP }\end{array}$ & $\begin{array}{c}\text { Conventional } \\
\text { age BP }\end{array}$ & $\begin{array}{c}\text { Calibrated age } \\
1 \sigma \mathrm{BP}\end{array}$ & $\begin{array}{c}\text { Calibrated age } \\
1 \sigma \mathrm{BP}\end{array}$ & $\begin{array}{c}\text { Sample } \\
\text { description }\end{array}$ \\
\hline CAST5 & 125045 & $\mathrm{R}, \mathrm{BLC}$ & $-25.5 \%$ & $5150 \pm 60$ & $5150 \pm 60$ & $5940-5890 / 5795-5780$ & $6005-5745$ & $\begin{array}{l}\text { Alluvial deposit } \\
\text { (silt) }\end{array}$ \\
\hline CAST6 & 125046 & $\mathrm{R}, \mathrm{BLC}$ & $-25.6 \%$ & $3740 \pm 70$ & $3730 \pm 70$ & $4155-3965$ & $4275-3870$ & $\begin{array}{l}\text { Colluvium } \\
\text { (silt) }\end{array}$ \\
\hline CAST9 & 125048 & $\mathrm{R}, \mathrm{BLC}$ & $-25.6 \%$ & $1850 \pm 60$ & $1840 \pm 60$ & $1840-1705$ & $1885-1600$ & $\begin{array}{l}\text { Colluvium } \\
\text { (silt) }\end{array}$ \\
\hline CAST10 & 125049 & $\mathrm{R}, \mathrm{BLC}$ & $-25.7 \%$ & $1670 \pm 60$ & $1660 \pm 60$ & $1600-1510$ & $1705-1400$ & $\begin{array}{l}\text { Colluvium } \\
\text { (silt) }\end{array}$ \\
\hline CAMP1 & 106260 & AMS & $-28.1 \%$ & $10020 \pm 70$ & $9970 \pm 70$ & $\begin{array}{c}11637-11608 / 11596- \\
11592 / 11580 \\
-11329 / 11323- \\
11297 / 11272-11261\end{array}$ & $9824-9045$ & $\begin{array}{l}\text { Charcoal } \\
\text { fragments } \\
\text { within } \\
\text { alluvial } \\
\text { deposits }\end{array}$ \\
\hline CAMP4 & 118167 & $\mathrm{R}, \mathrm{BLC}$ & $-26.2 \%$ & > 39640 & > 39630 & / & l & $\begin{array}{l}\text { Colluvium } \\
\text { (clayey silt) }\end{array}$ \\
\hline CAMP7 & 106261 & AMS & $-27.1 \%$ & $7490 \pm 50$ & $7460 \pm 50$ & $8320-8150$ & $8345-8125$ & $\begin{array}{l}\text { Charcoal } \\
\text { fragments } \\
\text { within } \\
\text { alluvial deposits }\end{array}$ \\
\hline CAMP12 & 128977 & $\mathrm{R}, \mathrm{BLC}$ & $-28.7 \%$ & $33180 \pm 470$ & $33120 \pm 470$ & / & l & $\begin{array}{l}\text { Lacustrine } \\
\text { organic silt }\end{array}$ \\
\hline CAMP15 & 142196 & $\mathrm{R}, \mathrm{BLC}$ & $-24.4 \%$ & $1230 \pm 40$ & $1240 \pm 40$ & $1245-1135 / 1110-1095$ & $1270-1065$ & $\begin{array}{l}\text { Buried soil } \\
\text { (silty sand) }\end{array}$ \\
\hline CAMP17 & 7163998 & $\mathrm{R}$ & $-25.0 \%$ & $2430 \pm 120$ & $2430 \pm 120$ & $2730-2340$ & $2770-2290 / 2270-2160$ & $\begin{array}{l}\text { Buried soil } \\
\text { (silty sand) }\end{array}$ \\
\hline CAMP20 & 120600 & AMS & $-25.1 \%$ & $7650 \pm 60$ & $7650 \pm 60$ & $8425-8365$ & $8500-8330$ & $\begin{array}{l}\text { Organic silt } \\
\text { (colluviated } \\
\text { paleosol?) }\end{array}$ \\
\hline CAMP21 & 142197 & $\mathrm{R}, \mathrm{BLC}$ & $-24.2 \%$ & $9200 \pm 230$ & $9220 \pm 230$ & $10685-10190$ & $11150-9730$ & $\begin{array}{l}\text { Colluvium } \\
\text { (silt) }\end{array}$ \\
\hline
\end{tabular}

trench sites. Four trenches were excavated across those splays affecting the younger deposits and landforms and samples collected for radiocarbon dating (table I) or mineralogical analysis. Radiocarbon dating was generally done on bulk sediments. Dated units are related to colluvial (CAST-6, -9, -10, CAMP-21) or alluvial (CAST-5, CAMP-1, -7) deposition. Dating of colluvial deposits generally gives, however, only the lower chronological limit for the deposition. Paleosols were dated in the trench excavated across the Laga Mts. Fault (CAMP-15, -17). In this case, sampling was done on the A horizons of the soils. One wood fragment (CAMP-11) was also collected from displaced deposits along the Laga Mts. Fault.

Samples for radiocarbon dating were analysed by Beta Analytic Inc. (Miami, U.S.A.). Two samples (CAMP-4, -11) gave evidence of an age older than the limit of the method. Radiometric counting was generally employed. In three cases (CAMP-1, -7, -11), due to the lower sample size, AMS counting was used.

The conventional radiocarbon ages obtained (all standard analyses; table I) were calibrated by Beta Analytic (if conventional ages were younger than 19000 years BP) using the INTCAL98 database reported in Stuiver et al. (1998). Ages reported in the text represent the $1 \sigma$ calibrated results ( $68 \%$ of probability). Table I, however, also reports the $2 \sigma$ values, thus permitting the reader to define the chronological constraints of the displacement events based on the $2 \sigma$ chronology.

Further chronological constraints were derived from the Late Pleistocene-Holocene stratigraphic setting of the investigated region which is particularly well known, for the moun- 
tainous area, through investigations made with a paleoclimatological perspective since the end of the $80 \mathrm{~s}$ (e.g., Frezzotti and Giraudi, 1989, 1990a,b; Frezzotti and Narcisi, 1989, 1996; Giraudi, 1994, 1995, 1998a,b, 2000; Giraudi and Frezzotti, 1997). In these works, the authors define the stratigraphy of continental Late Pleistocene-Holocene deposits of various facies (glacial, fluvioglacial, alluvial, aeolic, etc.) also reporting fundamental information about the paleosols which have formed for about 30000 years BP. Detailed chronological constraints are also given.

\section{Mt. Vettore - Castelluccio Plain}

\subsection{Geomorphic analysis}

The Mt. Vettore normal fault is NNW-SSE to NW-SE trending and is about $18 \mathrm{~km}$ long (figs. $1,2 \mathrm{a}, \mathrm{b}$ and $3 \mathrm{a}, \mathrm{b})$. It is located in a high mountainous environment, since Mt. Vettore reaches $2476 \mathrm{~m}$ a.s.l. Only one major intermontane basin formed along the fault, i.e. the Castelluccio Plain (fig. 3a,b). According to Coltorti and Farabollini (1995), deposition in the piedmont area is related to the abundant clastic material produced by
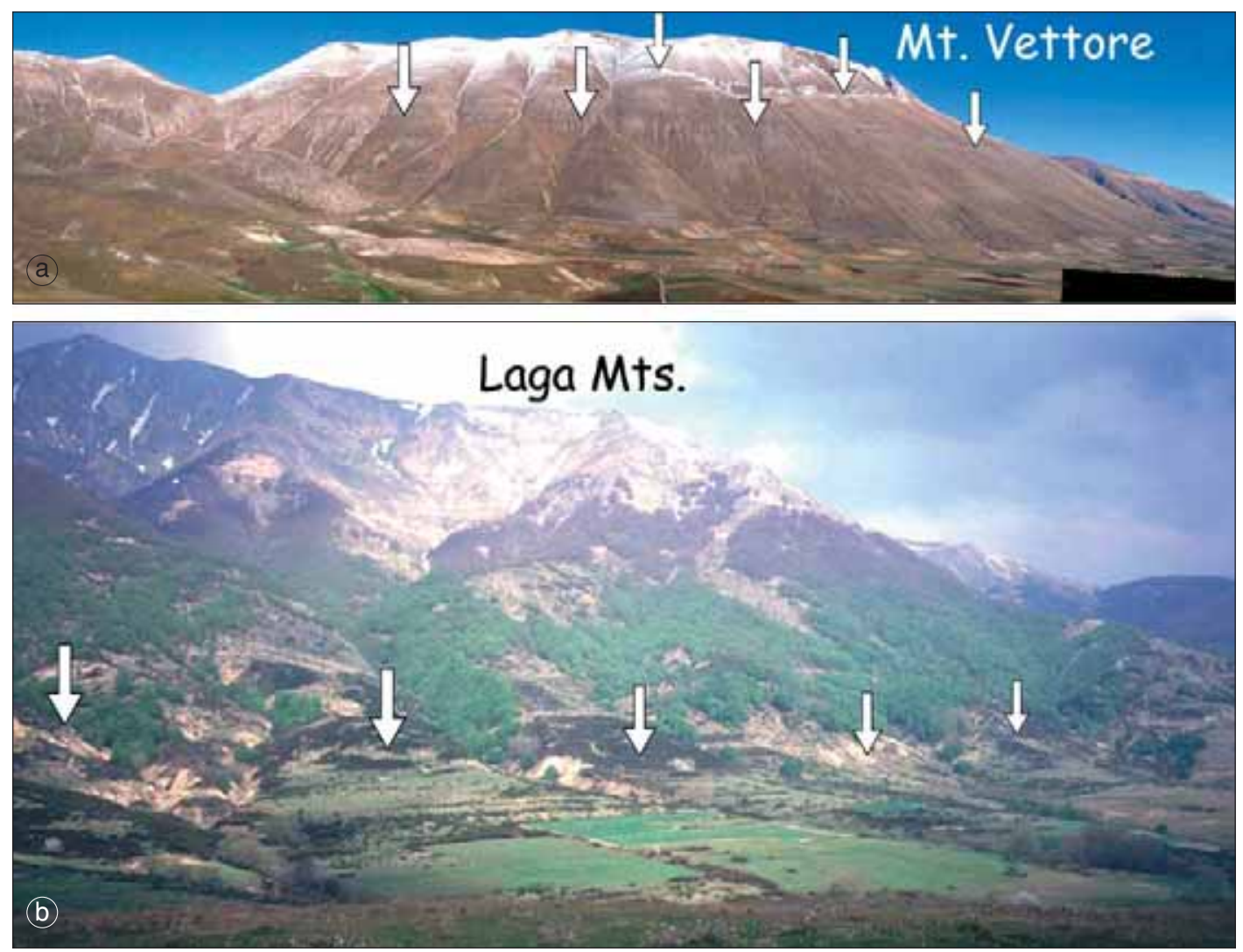

Fig. 2a,b. Panoramic views of the two areas paleoseismologically investigated. a) View of the Western Mt. Vettore slope, characterised by two bedrock fault scarps (marked by the arrows); the trench sites (not visible in the photograph) are located in the flat area at the foot of the slope (see next figures for further details). b) View of the SW slope of the Laga Mts.; the arrows mark the scarps presumably related to the Holocene activity of the fault (the trench site is located to the right of the photograph, see next figures for further details). 


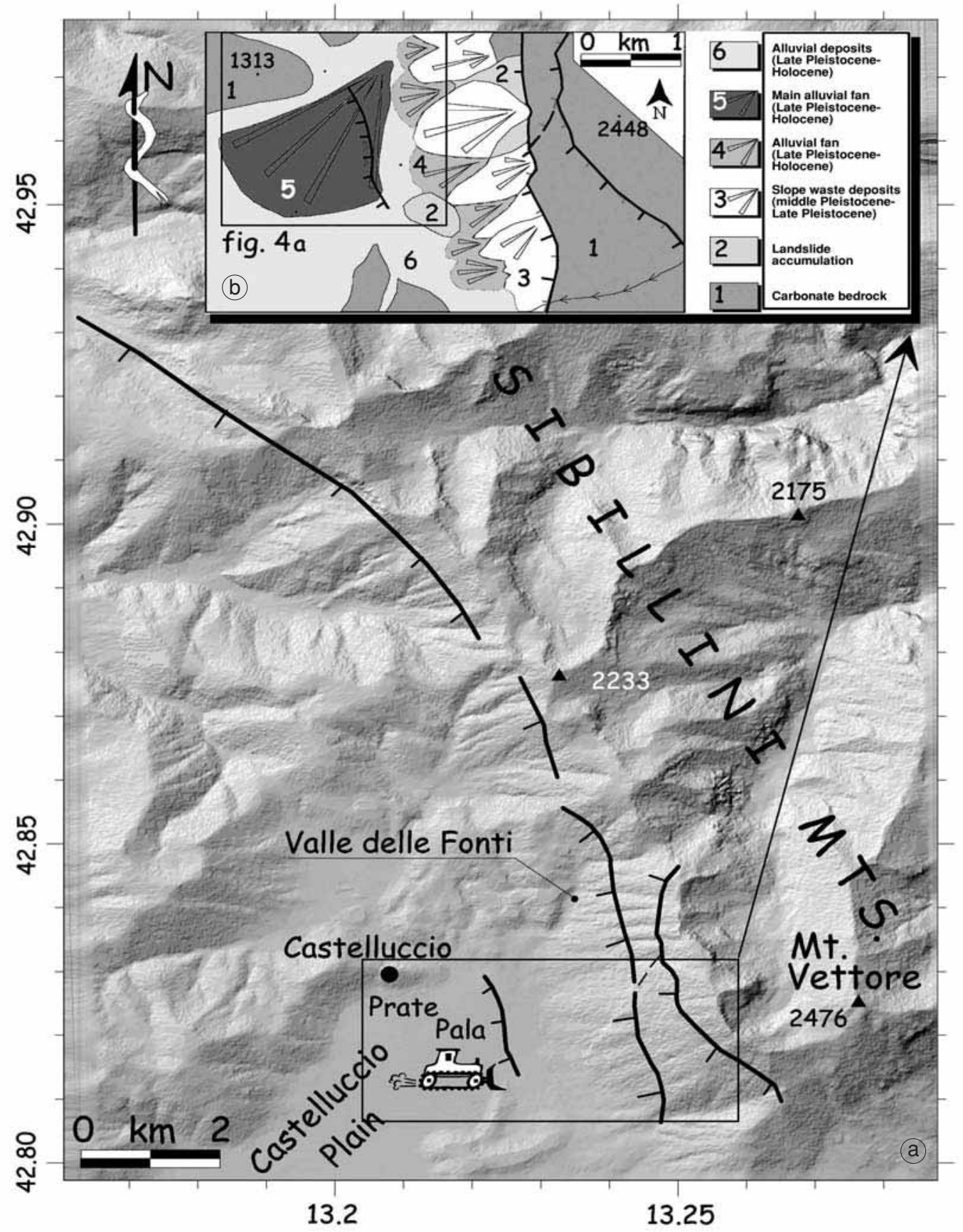

Fig. 3a,b. a) Map of the Mt. Vettore fault area; the trenches were excavated across the minor segment located in the Prate Pala area. b) Geomorphological map of the Castelluccio Plain: the Prate Pala scarp affects the large Late Pleistocene-Holocene alluvial fan fed from the Valle delle Fonti area. 
the Mt. Vettore SW slope (fig. 3b). These authors mapped slope deposits and landslide accumulations in the most elevated areas, while they reported alluvial deposits and landforms in the piedmont area. We analysed a large alluvial fan (fig. 3b) fed by the Valle delle Fonti creek (Castelluccio fan), through the use of aerial photographs, and recognised five different depositional phases (fig. 4a). These phases are known throughout the Central Apennines (e.g., the Majelama alluvial fan, Frezzotti and Giraudi, 1992; the Campo Imperatore alluvial fans, Giraudi, 1994). Available works related the 1 st depositional phase to the Last Glacial Maximum (LGM, about 22600 years BP in the Central Apennines, i.e. the Campo Imperatore Stade in Giraudi and Frezzotti, 1997), while the 4th and the 5th phases are related to the boundary Late Pleistocene-Holocene and to about 3800-3200 years BP, respectively. No chronological constraints are available for the 2nd and 3rd alluvial phases. The Castelluccio Plain is, therefore, partly filled by an alluvial fan which probably formed between about 23000 and 3200 years BP.

Two fault splays are easily detectable along the Mt. Vettore western slope, since they formed impressive limestone scarps. In particular, the easternmost scarp is several metres high and shows a fault plane displacing only the carbonate bedrock. The westernmost fault, in contrast, places the bedrock in contact with Late Pleistocene slope deposits. Based on this geomorphic evidence, the fault was considered active by Calamita and Pizzi (1992) and Cello et al. (1997). More recently, Galadini and Galli (2000) confirmed the recent fault activity by reporting the evidence of displacements affecting recent deposits in the piedmont area. In particular, during 1997-1998, the authors made analyses on the Mt. Vettore Fault and investigated a scarp (Prate Pala scarp; fig. 4b,c) in the Castelluccio alluvial fan, not reported in the previous works. The Prate Pala scarp formed into the gravel of the alluvial fan and, in particular, it affects the top surfaces related to the 4 th and 5 th alluvial phases. We interpreted it as the result of recent fault activity, since it is completely divergent from the drainage which recently developed on the alluvial fan and small creeks appear to be displaced across the scarp (fig. 4a).
Two topographic profiles were made to estimate the height of the Prate Pala scarp (fig. 4b,c). This height is about $3.3 \mathrm{~m}$ in the area of the 4th alluvial fan, while it is about $2 \mathrm{~m}$ in the area of the 5th alluvial fan. The trenches made across the scarp in the area of the 4th alluvial fan (see below) showed that these values result from correlation of different surfaces on both sides of the scarp. The topographic surface of the footwall area has an erosional origin and is carved into the gravels, while the surface in the hangingwall is a top depositional surface of colluvial units (see sections dedicated to the trench analysis). If we consider that about $1 \mathrm{~m}$ of colluvial units deposited in the hangingwall (as derived from paleoseismological data), the vertical offset affecting the 4th alluvial fan is $4.3 \mathrm{~m}$. Since the 4th alluvial fan can be related to the boundary Late Pleistocene-Holocene (about 12000 years BP), the vertical slip rate is $0.36 \mathrm{~mm} / \mathrm{yr}$.

The 5th alluvial fan can be related to about 3800-3200 years BP. In this case, considering the vertical offset of $2 \mathrm{~m}$, the slip rate is $0.52-0.62$ $\mathrm{mm} / \mathrm{yr}$.

Since the Mt. Vettore Fault Zone is made of at least three parallel splays, the reported values define minimum slip rates for the entire structure. In short, the minimum slip rate for the Mt. Vettore Fault ranges between 0.36 and $0.62 \mathrm{~mm} / \mathrm{yr}$.

Three trenches were dug across the Prate Pala scarp and due to logistic problems (the Castelluccio Plain is intensely cultivated) we had the opportunity to make the excavations only in the area of the 4th alluvial fan. The depth of the trenches was always conditioned by the presence of the gravels, generally showing a massive texture, which are not useful for the definition of the faulting history, due to their homogeneity across the fault. Moreover, the trenches showed the same stratigraphic succession and structural setting. For this reason, we report a detailed description of trench 1 and the few differences observed in trenches 2 and 3 .

\subsection{Paleoseismology}

\subsubsection{Trench 1}

The Castelluccio alluvial fan is entirely made of gravels and for this reason we decided 

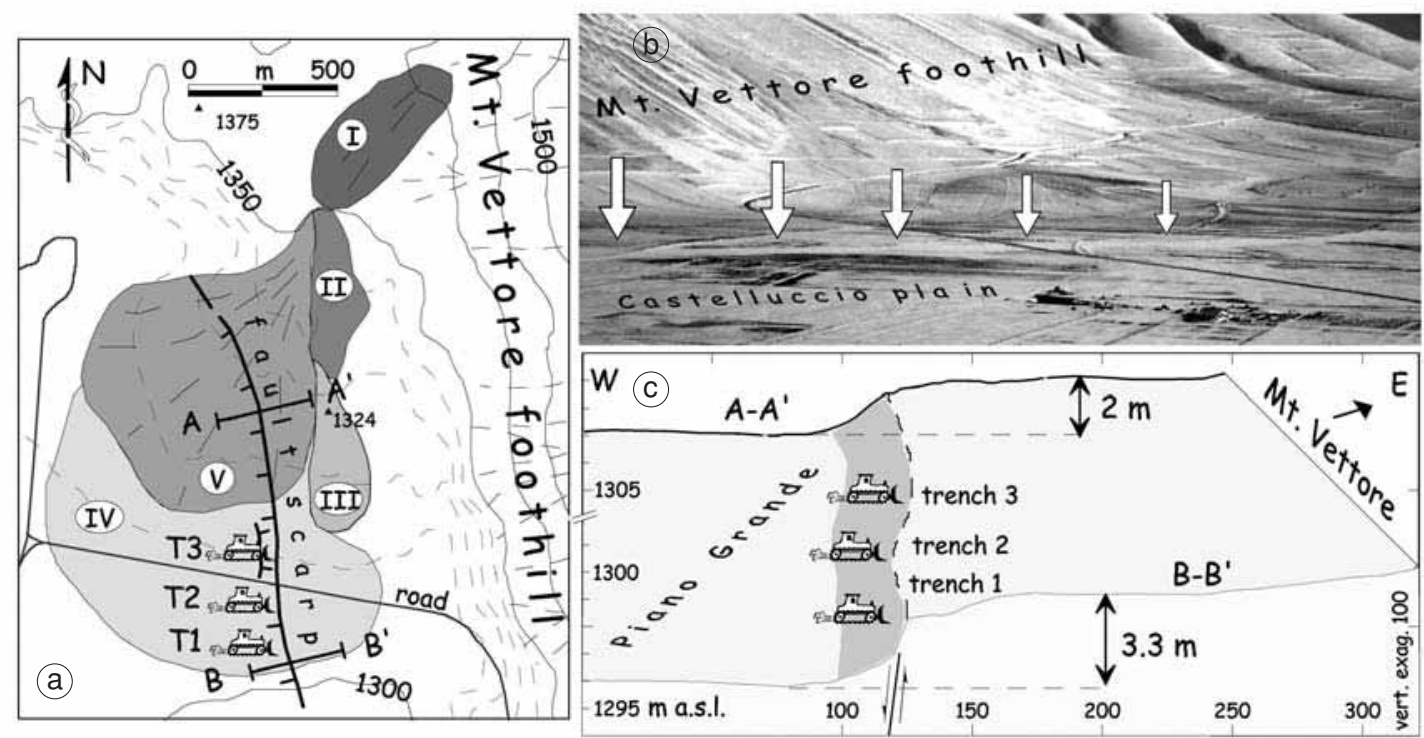

Fig. 4a-c. a) Geomorphological map of the Castelluccio alluvial fan: the fan resulted from the deposition during five different alluvial phases. b) Panoramic view of the scarp on the alluvial fan (note the slope of the road when it crosses the scarp). c) 3D view of the scarp (vertically exaggerated), location of the trenches and scarp height as derived from the profiles $\mathrm{A}-\mathrm{A}^{\prime}$ and $\mathrm{B}-\mathrm{B}^{\prime}$ reported in fig. 4a.

to focus our attention on the most superficial units. The origin of most of these units $(2,3,4$ in fig. 5a,b) is colluvial and therefore the radiocarbon ages (1600-1510 years BP, 1840-1705 years BP, 4155-3965 years BP, $1 \sigma$ cal ages for units $2,3,4$, respectively) define lower chronological limits for the deposition. However, the colluvial events to which units 2 and 4 are related have not only a local importance, since these units were found in all the trenches investigated. They were also found in a small excavation we made $300 \mathrm{~m}$ north of the trench area for stratigraphic purposes. It is therefore probable that these colluvial phases affected a large part of the Castelluccio alluvial fan and that the re-deposition of former sediments/soils occurred during periods of climatic instability. Some constraints about the deposition of unit 2 may derive from the climatic history of the investigated region. A colluvium such as that of unit 2 is generally related to the mobilization of surficial soils which are no more in equilibrium with the environment of formation. This lack of equilibrium is due to the modification of the climatic conditions which permitted the pedogenesis. The climatic change chronologically close (and subsequent) to the reported radiocarbon date was identified in the Central Apennines as having occurred during the 6th-7th century A.D. In particular, since in this period a glacial advancement occurred in the Gran Sasso Chain area (see fig. 1 for location), defined as Calderone $3 \mathrm{a}$ stade (Giraudi, in press). This glacial advancement is consistent with the increase in the lacustrine level in the Fucino Lake (see fig. 1 for location) during the 7th century A.D. (Giraudi, 1998a) and probably represented the effect of a widespread climatic change towards cooler and drier conditions, as suggested by similar chronological constraints for the advancement of Alpine glaciers (Orombelli and Porter, 1982; Strumia, 1997). Unit 2 may have been deposited, therefore, during the 6th-7th century A.D.

Unit 3 is lithologically similar to unit 2, as for the fine fraction. The carbonate pebbles are, however, finer and sparser than in the unit pre- 
viously described. The maximum thickness is about $50 \mathrm{~cm}$. An origin similar to that of unit 2 can be defined for unit 3. The sandy fraction gave a date of 1840-1705 years BP ( $1 \sigma$ cal age). Due to the colluvial origin of unit 3 , the same problems defined for unit 2 about the implications of the obtained date may be outlined for unit 3 .
As for unit 4, the high content of organic matter and the monogenic origin of the deposit (containing very few pebbles) suggest that the colluvium originated from re-deposition of an exposed A-horizon of a soil. For this reason the obtained radiocarbon date cannot be far from the age of colluviation.

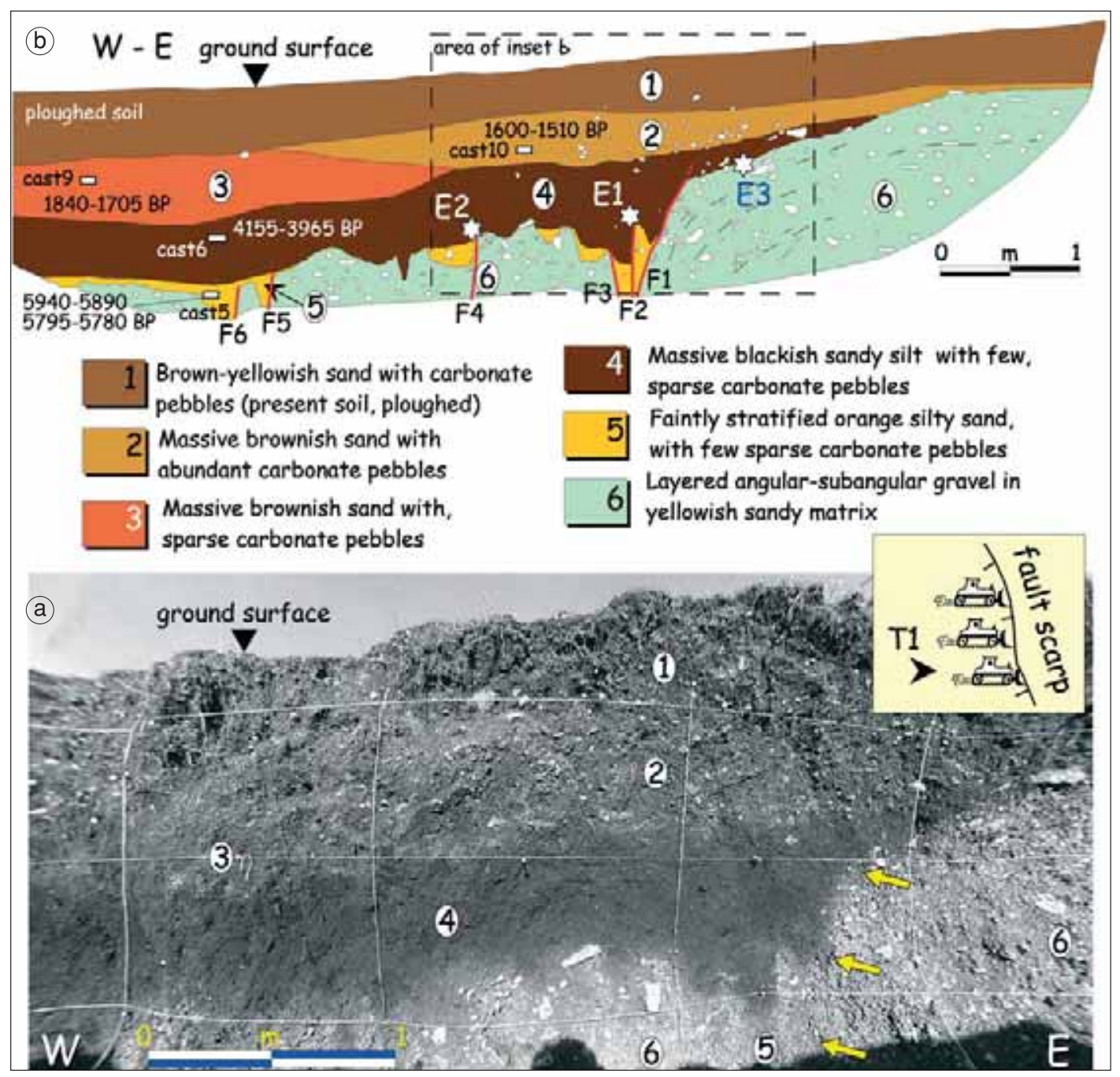

Fig. 5a,b. a) Log of the $\mathrm{N}$ wall of trench 1 excavated across the Prate Pala fault scarp (Mt. Vettore Fault); the analysis of the wall defined the occurrence of three displacement events. b) Panoramic view of trench 1 ( $\mathrm{N}$ wall). 
Finally, the sedimentological characteristics (faintly stratified silty sands) of unit 5 (radiocarbon dated at 5940-5890/5795-5780 years BP, $1 \sigma$ cal age) define an alluvial origin.

Major (F1) and minor (F2 to F6) faults place the carbonate gravel (unit 6 ) in contact with the colluvial and alluvial units 4 and 5 (fig. 5a,b). Considering the whole geometry, F3 is probably the antithetic fault of F1. Among these two faults, a minor shear plane (F2) displaces units 4 and 5 .

Due to the reduced height of the trench, the fault planes are exposed for a few tens of centimetres, but show a high-angle dip $\left(70^{\circ}-80^{\circ}\right)$. The main component of the movement is vertical, as indicated by the sinking of the gravels (unit 6) in the central part of the trench, the preservation of unit 5 and the thickness increase of unit 4 in the same area. Moreover, the dip towards west of the unit 6 layers (fig. 5a,b) (while the alluvial fan deposition occurs towards south), together with the pebble imbrication related to similarly directed paleocurrents, probably results from gravel deposition controlled by the $\mathrm{N}-\mathrm{S}$ tectonically-induced depression.

The youngest displacement event (E1) occurred after the deposition of unit 4 which is the uppermost unit displaced by the faults F1 and F2. This event occurred, therefore, after 4155-3965 years BP ( $1 \sigma$ cal age, which is close to the deposition age of unit 4) and before the deposition of unit 2 which seals the fault planes, that is before the 6th-7th century A.D. The preservation of unit 4 only in small sectors of the footwall suggests areal erosion event after the displacement event. This erosional event erased the scarp-derived colluvium which possibly formed after the displacement.

The vertical displacement of the base of unit 4 across fault F1 can be roughly estimated in $0.45 \mathrm{~m}$, if an average line representing the base of this unit in the hangingwall is projected on the fault plane and the vertical separation with the same line at the footwall is calculated. This value is a minimum estimate, since the progressively higher elevation of the unit 4 base towards NE in the footwall is probably due to the fault-related displacement.

A previous event (E2) affected units 5 and 6 before the deposition of unit 4 . This is suggested by the lack of unit 5 in the footwall, between units 6 and 4. This means that unit 5 was displaced and eroded before the deposition of unit 4. Further evidence for the occurrence of event E2 is represented by the minor fault planes F4, F5 and F6, which affect units 5 and 6 , being sealed by unit 4 . The event E2 occurred after $5940-5890 / 5795-5780$ years BP ( $1 \sigma$ cal age, unit 5) and before 4155-3965 years BP which, based on the considerations about the origin of unit 4 (see section dedicated to the stratigraphy) may represent an age close to the deposition of this unit. Due to the irregular depositional surface and the limited exposure of unit 5, the vertical offset related to E2 cannot be defined.

A previous event or phase of events (E3) may be indicated by the faint layering of unit 6 , dipping westwards and an imbrication of the pebbles indicating similarly directed paleocurrents. The deposition and therefore the attitude of unit 6 have been conditioned by the presence of a lowered area west of the fault F1. This lowered area suggests the occurrence of displacement events along the fault F1 before the deposition of unit 5 . Therefore the fault activity occurred before 5940-5890/5795-5780 years BP and after the deposition of unit 6 which, based on the geomorphological setting and the correlation with the succession of other Central Apennine alluvial fan (see previous section), may have occurred about 18000-12000 years BP.

\subsubsection{Trench 2}

The trench was excavated $40 \mathrm{~m}$ north of trench 1. Unit 7 is made of gravels in abundant sandy matrix. The texture is matrix-supported, the pebbles are angular or sub-angular, with long axes highly-dipping towards W. The described attitude suggests a deposition over a west-dipping scarp. Since these deposits can only be detected in the fault zone and show typical colluvial characteristics, we interpret unit 7 as a colluvial wedge resulted from the retreat of a scarp carved into the gravels of unit 6 .

Numerous shear planes affect the investigated section ( $\mathrm{N}$ trench wall) and have been responsible for the displacement of units 4, 5, 6 and 7 (fig. 6a,b). Some shear planes (F7, F10) are sealed by unit 4, other (F6 and F11) 


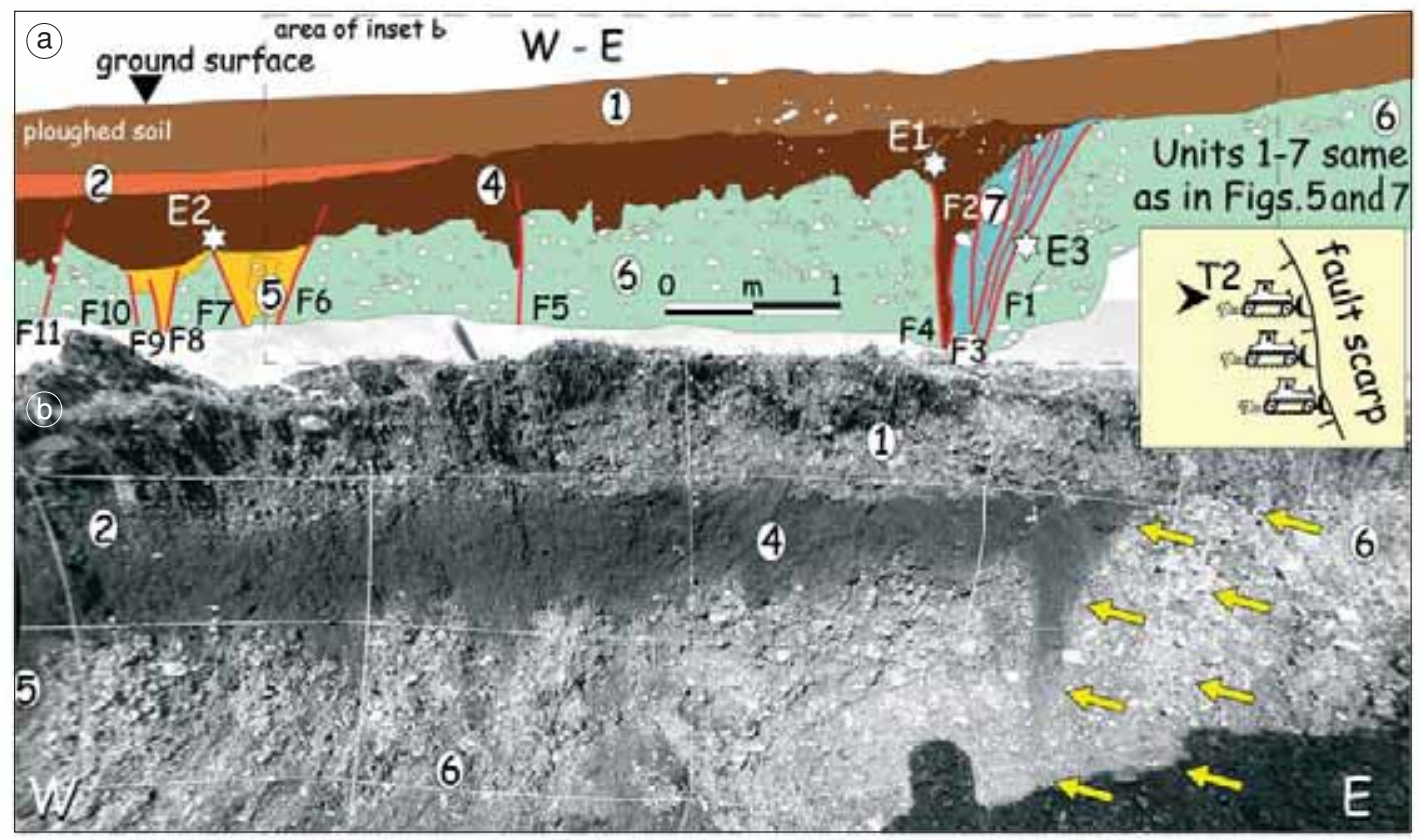

Fig. 6a,b. a) Log of the $\mathrm{N}$ wall of trench 2 excavated across the Prate Pala fault scarp (Mt. Vettore Fault); units are the same of fig. 5a,b; the paleoseismological analysis defined the occurrence of three displacement events. b) Panoramic view of trench 2 ( $\mathrm{N}$ wall).

are sealed by unit 2, while the shear planes F1 to F5 are sealed by unit 1.

The youngest displacement event (E1) occurred after the deposition of unit 4 and was detected along the fault planes F2 to F6 and the fault plane F11. The available date for unit 4 (derived from trench 1, 4155-3965 years BP) represents the lower chronological limit. The upper chronological limit, similarly to trench 1 , may be defined by the 6th-7th century A.D. (see previous section). The presence of unit 4 between fault planes F3 and F4 at depth (fig. 6a) suggests that faulting of unit 4 was also responsible for the formation of an open fissure between the mentioned fault planes (subsequently filled by the same faulted material of unit 4). Since the bottom of unit 4 is very irregular and this unit is not present in the footwall, the vertical offset cannot be estimated.

The interpretation of unit 7 as a colluvial wedge due to the retreat of a former scarp defines an older event (E2), as this unit was fault- ed during E1. Since unit 4 deposited over this colluvial wedge (see the sector between the fault planes F1 and F2), the scarp which fed the colluvium formed - and the related event occurred - before 4155-3965 years BP (approximate deposition age of unit 4). This event may be the same as that responsible for the displacement of unit 5 in the western portion of the trench. In this case, the occurrence of an event before the deposition of unit 4 is suggested by the fact that this unit seals the fault planes F7 and F10. The lower chronological limit for E2 along F6 to F10 is defined by the age of unit 5 (5940-5890/57955780 years BP). Due to the lack of correlative deposits in the eastern and western parts of the trench, the vertical offset cannot be defined.

Also in trench 2, a previous event (E3) may be defined by the gentle dip of unit 6 towards west, i.e. towards the area lowered by the fault activity. The dip of the gravel is probably due to the presence of a tectonically subsiding area also before the deposition of the younger units 
(5 to 1 ). This event or phase of events has, therefore, the same chronological constraints defined for trench 1, i.e. E3 occurred between 1800012000 years BP (probable age of unit 6) and 59405890/5795-5780 years BP (age of unit 5).

\subsubsection{Trench 3}

Trench 3 was excavated between the previously described trenches. Also in this case we investigated the $\mathrm{N}$ trench wall (fig. 7a,b).

The stratigraphic succession (units 4, 5 and 6) is affected by 8 shear planes defining fault activity before the deposition of unit 2 , sealing the detected faults. A pervasively sheared area was detected between fault planes F1 and F4; shear planes were responsible for the warping of units 4 and 5 and the re-orientation of the pebbles of unit 6. We only reported the major shear planes ( $\mathrm{F} 1$ to F3) affecting this highly deformed area (fig. 7a).

The most recent event (E1) is indicated by the displacement of unit 4 along fault planes F1, F4 and F7 and by the continuous deformation between fault planes F1 and F4, responsible for the gentle dip towards $\mathrm{W}$ of the limits between units 4, 7 and 6 . The displacement occurred after the deposition of unit 4, i.e. after 4155-3965 years BP. Also in this case, on the basis of the discussion of trench 1 (see previous sections), the upper chronological limit of this event is represented by the colluvial deposition (unit 2) probably related to the 6th-7th century A.D. Since unit 4 is almost absent in the footwall, it is not possible to precisely define the vertical offset. An estimate of the minimum vertical offset may be obtained by computing the vertical separation $(1.2 \mathrm{~m})$ between the base of unit 4 in the hangingwall and the limit unit 6/unit 2 (indicating the occurrence of erosional activity responsible for the erasure of unit 4) in the footwall (fig. 7a,b). The assumption of a subhorizontal attitude of the unit 4 depositional surface is necessary to consider this estimate as a reliable minimum vertical offset. We believe, however, that a local topography gently dipping westwards characterised the investigated area also before the deposition of unit 4 (as suggested by the fact that such kind of topography characterised the area during the deposition of unit 6 , gently dipping towards $\mathrm{W}$,

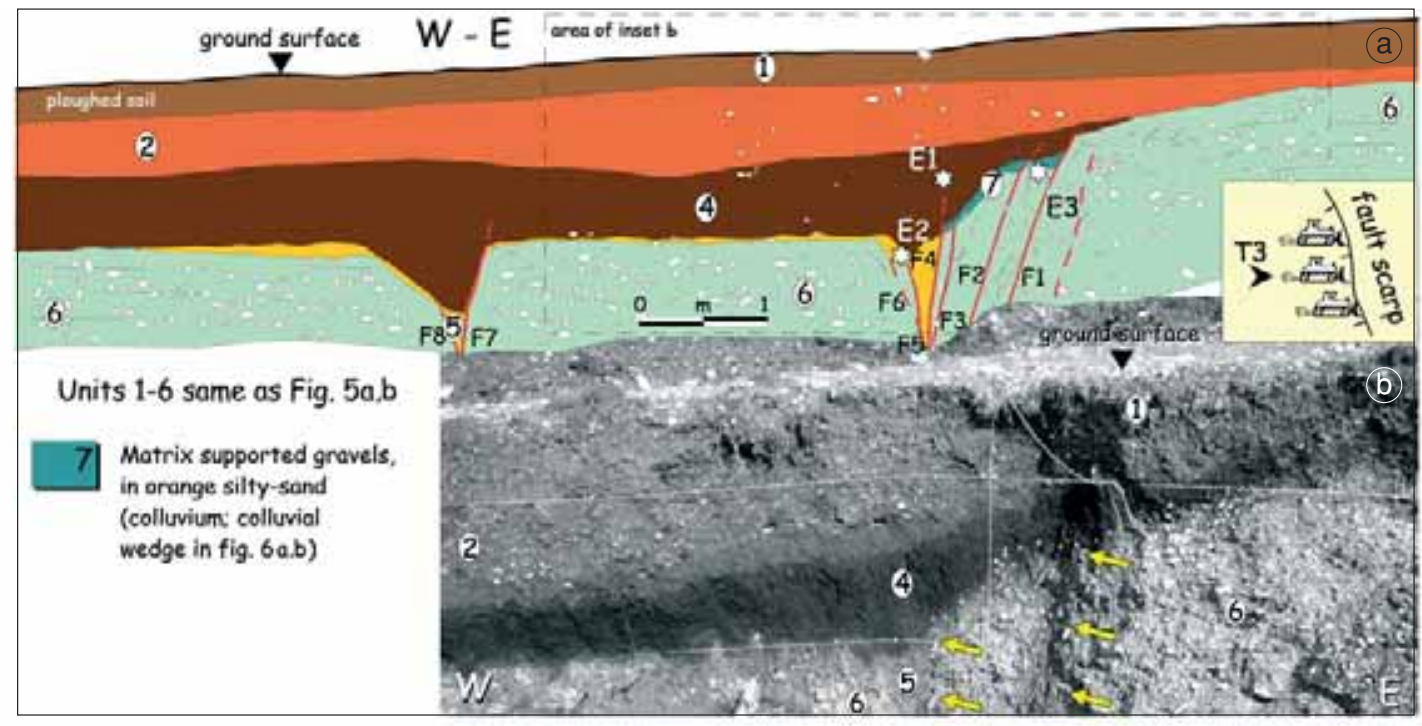

Fig. 7a,b. a) Log of the $\mathrm{N}$ wall of trench 3 excavated across the Prate Pala fault scarp (Mt. Vettore Fault); units are the same of fig. 5a,b; the paleoseismological analysis defined the occurrence of three displacement events. b) Panoramic view of trench 3 ( $\mathrm{N}$ wall). 
and by the present topography). The estimate of the minimum vertical offset has to be taken, therefore, with caution.

As already observed for the other trenches, a previous event (E2) affected units 5 and 6 before the deposition of unit 4 , as suggested by the presence of fault planes (F5 and F6) sealed by the latter unit and by the lack of unit 5 in the footwall (east of F1), between units 4 and 6 (indicating erosion of unit 5 after its displacement and before the deposition of unit 4). The displacement occurred, therefore, after 5940-5890/57955780 years BP (age of unit 5) and before 4155 3965 years BP (approximate depositional age of unit 4). Since unit 5 is scarcely exposed in the hangingwall and is absent in the footwall, it is not possible to give an estimation of the vertical offset of this unit. The presence of unit 5 between the fault planes F4 and F5 suggests that during E2 a fissure opened and was filled by the sediments of unit 5 .

As in the case of the previously described trenches, older displacement events (E3) are suggested by the gentle western dip of unit 6, indicating a deposition conditioned by the tectonically subsiding area bounded by the faults F1 to F6. The chronological constraints are the same as those defined for the previously described trenches, i.e. the lower chronological limit is $18000-$ 12000 years BP, while the upper limit is 59405890/5795-5780 years BP.

\subsection{Summary of the displacement events}

The three trenches excavated across the fault scarp in the Castelluccio alluvial fan showed the same displacement succession, with at least two events occurred during the Holocene.

The youngest event (E1) was chronologically constrained between 4155-3965 years BP and the 6th-7th century A.D.

An older event (E2) occurred between 59405890/5795-5780 years BP and 4155-3965 years BP.

While E1 and E2, easily detectable in all the investigated trenches, were interpreted as related to individual displacement events, E3 is probably related to a number of events which occurred between 18000-12000 years BP and 5940-5890/ 5795-5780 years BP.

\section{Laga Mts. - Campotosto Basin}

\subsection{Geomorphic analysis}

The NW-SE-trending Laga Mts. normal fault is $30 \mathrm{~km}$ long and bounds two intermontane basins: the Amatrice and Campotosto basins, located along the northern and southern portions of the fault, respectively (fig. 8). This fault was already considered active by

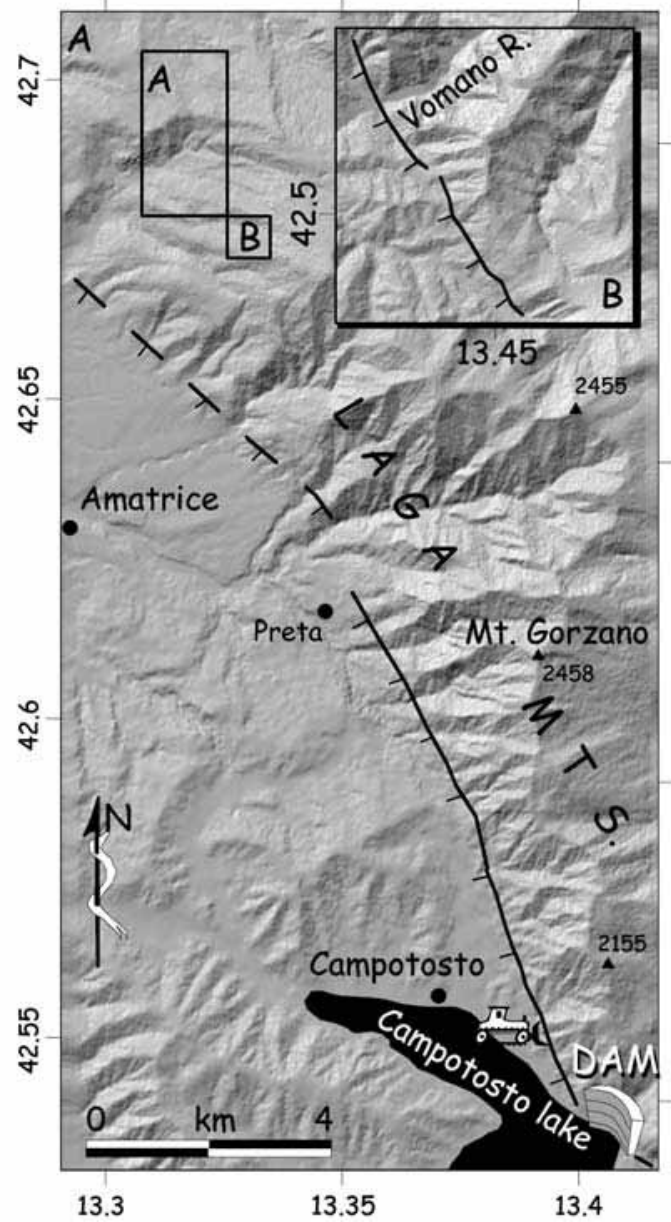

Fig. 8. Map of the Laga Mts. Fault. Clear evidence of Late Pleistocene-Holocene activity can be detected along most of the fault, apart from the northern portion (dashed) which was considered not active by Galadini and Messina (2001). 


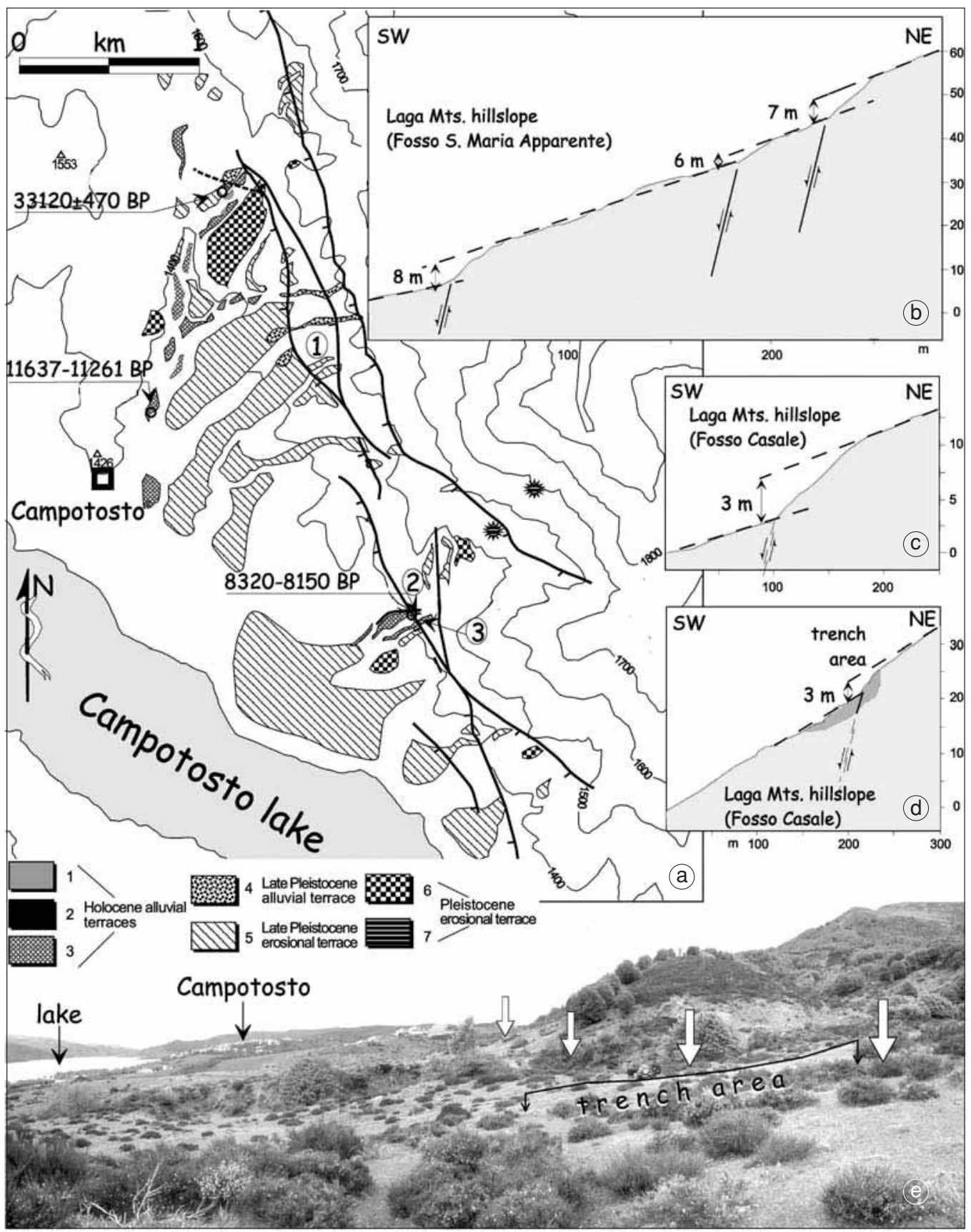

Fig. 9a-e. a) Geomorphological map of the Campotosto area; the trench was excavated at site 3; b,c,d) topographic profiles across the Laga Mts. Fault made at sites 1, 2 and 3, respectively; e) panoramic view of the trench site. 
Calamita and Pizzi (1994), Cello et al. (1997), Galadini and Galli (2000). More recent studies showed that Late Pleistocene-Holocene activity can only be related to the southern portion of the fault (Galadini and Messina 2001). These authors reported evidence of recent activity along a segment about $20 \mathrm{~km}$ long.

Lacustrine and alluvial deposits not older than the Late Pleistocene were found in the Campotosto Basin (fig. 9a-e), directly overlying the Miocene flysch. Deposits of an alluvial terrace (charcoal fragments within sand levels, sampled at two different sites, fig. 9a-e) gave radiocarbon ages of 11637 - 11608/11596 - $11592 /$ 11580 - $11329 / 11323$ - $11297 / 11272-11261$ years BP $(1 \sigma)$ and $8320-8150$ years BP $(1 \sigma)$.

In the area of the Campotosto Basin, the fault is made of three parallel splays affecting the Laga Mts. SW slope at different height (see fig. 9a for the central part of the fault). The western splay is the most interesting for the analysis of the recent faulting, since evidence of displacements of Late Pleistocene-Holocene deposits and landforms was found (Galadini and Galli, 2000). Evidence of recent activity is represented by fault scarps on the arenaceous bedrock and deposits related to terraces which formed along the incisions perpendicular to the slope (fig. 9a). Erosional flat landsurfaces in the piedmont area were also displaced by the westernmost splays of the fault zone (fig. 9a). Some scarps can be detected on Holocene terraces.

Complete information on the vertical offset was derived from the displacement of a terrace formed in a valley perpendicular to the Laga Mts. slope (site 1 of fig. 9a). This terrace is affected by all the main splays which form the fault zone. The topographic profile made along this terrace (fig. 9b) shows a total vertical offset of $21 \mathrm{~m}$ (Galadini and Galli, 2000). The displaced terrace is younger than a large erosional terrace carved into a lacustrine succession radiocarbon dated at $33120 \pm 470$ years BP (sampling site indicated in fig. 9a) and older than alluvial deposits radiocarbon dated at 11637 - 11608/11596 - 11592/11580 - 11329/11 323-11297/11272 - 11261 years BP $(1 \sigma)$. Based on the regional data about the chronology of the deposition in the piedmont areas of the Central Apennines (e.g., Dramis,
1983; Blumetti et al., 1993; Giraudi, 1996), a probable age of 20 000-30 000 years BP can be hypothesised for the displaced terrace. This led Galadini and Galli (2000) to estimate a vertical slip rate of $0.7-0.9 \mathrm{~mm} / \mathrm{yr}$.

A terrace formed over alluvial sandy deposits radiocarbon dated at $8320-8150$ years BP ( $1 \sigma$; Galadini and Galli, 2000) is affected by a fault scarp at site 2 (fig. 9a). An abandoned creek carved into this terrace (and therefore more recent than the reported date) was also displaced, as suggested by the presence of a fault scarp. The topographic profile made across the scarp (fig. 9c) defined a vertical offset of about $3 \mathrm{~m}$ (Galadini and Galli; 2000). Another topographic profile (fig. 9d) was made on the top of the displaced terrace, in the area chosen for trenching (site 3 in fig. 9a). This topographic profile defined a vertical displacement of $3 \mathrm{~m}$ occurred after 83208150 years BP $(1 \sigma)$. This represents, however, a minimum offset since the trench (see below) uncovered about $1 \mathrm{~m}$ of colluvial deposits in the hangingwall. This means that the vertical separation between the two correlative surfaces (top of the debris flow unit 11 in the paleoseismological section of fig. 10a,b, see next section) across the fault zone may be of about $4 \mathrm{~m}$. Considering that the footwall area experienced continuous erosion, this represents a minimum value for the vertical offset which defines a minimum vertical slip rate of $0.48-0.49 \mathrm{~mm} / \mathrm{yr}$. This slip rate is slightly higher than that $(0.3-0.36 \mathrm{~mm} / \mathrm{yr})$ defined by Galadini and Galli (2000) who did not consider the data subsequently derived from the trench.

The mentioned displaced terrace (site 3 of fig. 9a) was incised by the presently active torrent fed by the Laga Mts. after 8320-8150 years BP (age of the terrace alluvial sands). The trench site was located on the terrace remnant of the left valley flank (fig. 9e).

\subsection{Paleoseismology}

The trench was $32 \mathrm{~m}$ long and not deeper than $2.5 \mathrm{~m}$ (maximum depth reached in the fault zone; fig. 10a,b). The presence of deposits main- 


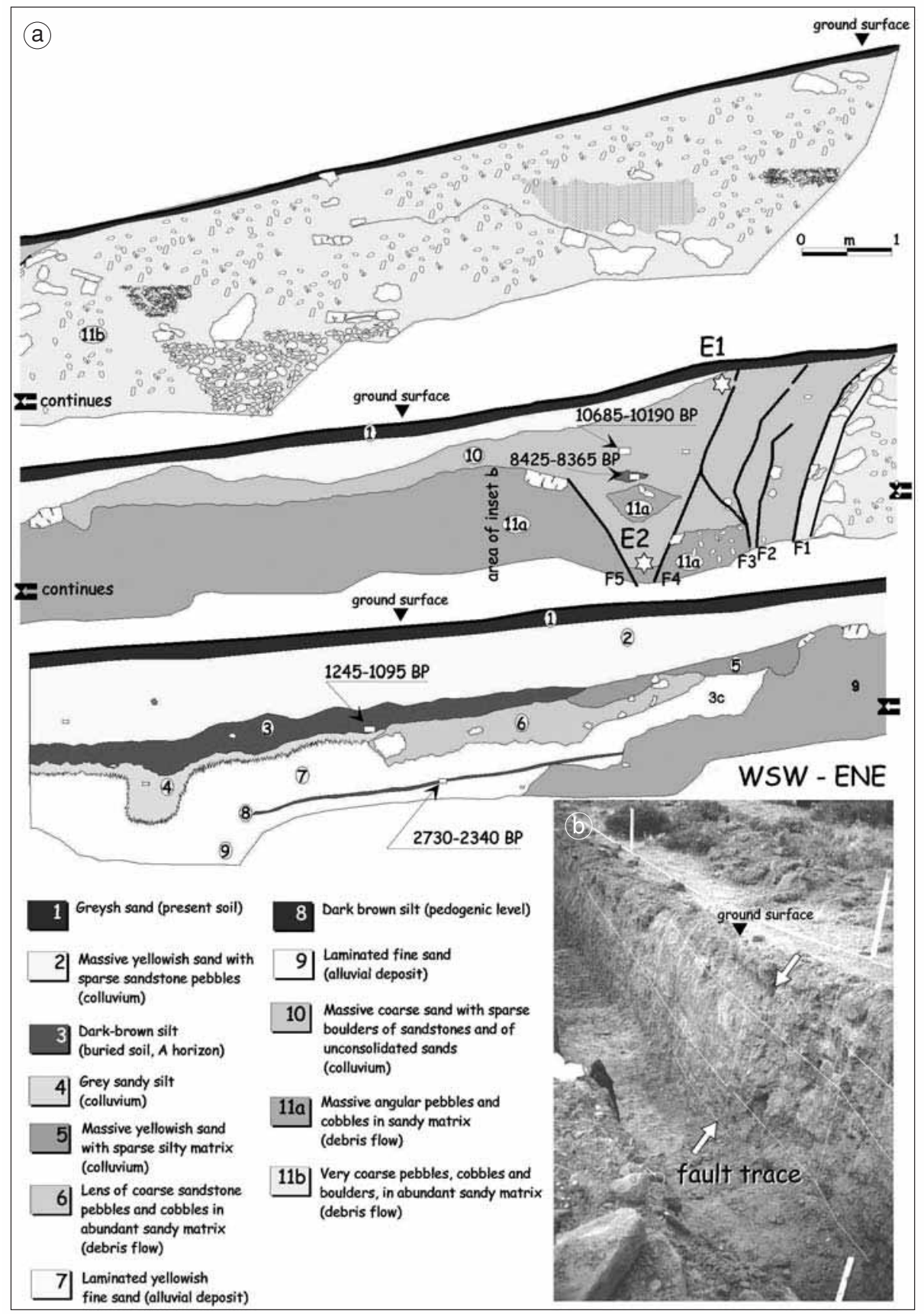

Fig. 10a,b. a) Log of the NW wall of the trench excavated across the Laga Mts. Fault at site 3 in fig. 9d; the paleoseismological analysis defined the occurrence of two displacement events after 8425-8365 years BP. b) Panoramic view of the investigated trench wall. 
ly made of sandstone boulders in sandy matrix (lowest stratigraphic levels) limited the depth of excavation. Fault planes within this kind of deposits are not easily recognisable and therefore we limited the excavation in the central portion of the trench at the top of the blocky unit.

Since the two trench walls showed the same stratigraphic features and defined the same history of displacement, only the NW trench wall will be described (fig. 10a,b).

Sandy units and deposits made of boulders, cobbles and pebbles in sandy matrix were exposed in the NW trench wall. Stratigraphy is definitely more variable than in the case of the Mt. Vettore Fault trenches. Figure 10a,b shows alternating coarse debris flow episodes (units 6, 11 in fig. 10a), fine-sediment colluvial $(2,4,5$, 10 in fig. 10a) and alluvial (7,9 in fig. 10a) deposits. The origin of the colluvial units 2 and 10 , i.e. the colluviums which deposited close to the fault zone (fig. 10a,b), is not clear. Indeed we have no data to understand if colluvial deposition is related to a process of scarp retreat or re-deposition in the piedmont area during phases of climatic instability.

Two different pedogenetic levels were identified (units 3 and 8). Chronological constraints are available for unit $3(1245-1135 / 1110-1095$ years $\mathrm{BP}, 1 \sigma$ cal age $)$, unit 8 (2730-2340 years BP, $1 \sigma$ cal age) and unit 10 (10685-10 190 years BP and 8425-8365 years BP, $1 \sigma$ cal age). Since the latter two dates are related to a sediment of colluvial origin, they define only a lower chronological limit for the deposition of unit 10 .

Part of the stratigraphic succession exposed in the NW trench wall (units 10,11a and 11b) is affected by five fault planes (F1 to F5 in fig. 10a). Faults F1 and F5 bound a small depression filled with the colluvial unit 10 . This structure shows a mainly normal component in the fault movement and extension roughly parallel to the trench direction. Fault F1 places the debris flow deposit (unit 11b) in contact with the colluvial unit 10 . F2 only affects unit 10 , while the other fault planes place unit 11a in contact with unit 10. F5 does not seem to displace unit 10 .

Two displacement events were recognized through the analysis of this trench.

The youngest event (E1) is indicated by the faults (F2, F3 and F4) affecting unit 10. Since unit
10 has a colluvial origin, its deposition occurred after the youngest radiocarbon date obtained for this unit (8425-8365 years BP, $1 \sigma$ ). E1 occurred, therefore, after this date. The upper chronological limit cannot be reliably defined, since F2, F3 and F4 are only sealed by the present soil. The lack of correlative deposits across the fault zone does not permit to define the vertical offset.

A previous event (E2) was responsible for the displacement of units $11 \mathrm{a}$ and $11 \mathrm{~b}$. In particular, it formed the depression between F1 and F5 filled by the colluvial unit 10 . The formation of this depression is, therefore, preceding the deposition of unit 10. The chronology of E2 cannot be, however, precisely defined, since the deposition age of unit 10 is poorly constrained (generically after $8425-8365$ years BP, $1 \sigma$ ). Therefore, if unit 10 is the product of colluvial deposition from the scarp formed during E2, this event may have occurred at about 8425-8365 years BP (youngest age of the presumed colluvial wedge). If unit 10 resulted from deposition during a period of climatic instability, i.e. the deposition was not conditioned by E2, the age of this displacement event cannot be defined.

In the previous section, however, we discussed a vertical offset of about $4 \mathrm{~m}$ of the terrace dated at $8320-8150$ years $\mathrm{BP}(1 \sigma)$. Since it is improbable that such a large offset is due to one displacement only (see sections dedicated to the fault behaviour), it may indicate that both E1 and E2 occurred after 8320-8150 years BP.

The analysis of the trench wall reported in fig. 10a defined a minimum value for the cumulated vertical offset from the stratigraphic data. If the base of unit 10 (exposed in the hangingwall, fig. 10a) had an almost regular attitude, the vertical separation between the top of unit $11 \mathrm{~b}$ in the footwall (where unit 10 was probably present before an erosional episode erased it) and the projection of the unit 10 base from the area SW of fault F5 on fault F1 gives a minimum vertical offset of $1 \mathrm{~m}$.

\section{Fault behaviour}

Paleoseismological data corroborate the previous hypothesis of repeated Holocene activation of the Mt. Vettore and Laga Mts. faults 
(Galadini and Galli, 2000 and references therein) mainly based on geomorphologic investigations.

The implications of the available data, in terms of slip rates, elapsed time since the last event, recurrence intervals and expected magnitude, will be discussed in the following sections.

\subsection{Slip rates}

The paleoseismological trenches were excavated across single splays of complex fault zones. For this reason, the data obtained on the vertical offsets from the trench analysis could only provide information on the minimum displacements which may be related to the entire structures. As for the Mt. Vettore Fault, we consider the Prate Pala scarp (across which the investigated trenches have been made) as the surficial expression of the westernmost splay within the fault zone. Therefore, we estimated a minimum slip rate. The topography of the Prate Pala scarp gave evidence for a minimum vertical slip rate ranging between 0.36 and 0.62 $\mathrm{mm} / \mathrm{yr}$ (see section dedicated to the geomorphic analysis). A slip rate can also be obtained from the displacement estimated through the trench analysis. A minimum vertical offset of $0.45 \mathrm{~m}$ affects the base of unit 4 of trench 1 (fig. 5a,b). Based on the age of the displacement (younger than 4155-3965 years BP and older than the 6th-7th century A.D.), a minimum vertical slip rate of $0.11-0.36 \mathrm{~mm} / \mathrm{yr}$ can be defined.

The trench made across the westernmost segment of the Laga Mts. Fault showed a minimum vertical offset of $1 \mathrm{~m}$ in the past 8425 years. This offset gives a minimum vertical slip rate of $0.12 \mathrm{~mm} / \mathrm{yr}$. In this case, however, more reliable information can be derived from the topographic profiles described in the section dedicated to the geomorphic analysis of the Laga Mts. Fault (Fig. 9a-e). By considering these topographic data, Galadini and Galli (2000) obtained a vertical slip rate of 0.7-0.9 $\mathrm{mm} / \mathrm{yr}$. Since this rate was obtained through the evaluation of the surface displacement across the entire fault zone, it can be considered a more realistic estimate of the fault behaviour.

\subsection{Elapsed time since the last activation}

The paleoseismological analysis did not define precise upper chronological limits for the displacements observed across the Laga Mts. Fault. Faulting can be observed throughout the entire stratigraphic succession below the present soil. The latter is, however, a very thin layer of humic material developed over a colluvial deposit. Radiocarbon dating of this layer is meaningless, since the obtained date would derive from the mixture of organic matter originated from the colluviated parent material and from the present humic matter. It is clear, therefore, that only the historical seismological information can cast light on the most recent activation of the Laga Mts. faults. Availableseismic catalogues (Boschi et al., 1995, 1997, 2000; Camassi and Stucchi, 1997; Working Group CPTI, 1999) give reliable information on the occurrence of large magnitude earthquakes since the first centuries of the 2nd millennium A.D. Historical data suggest that no earthquakes of $M>6$ affected the Central Apennines which may be related to the activation of the Laga Mts. Fault (Castelli et al., 2002). For this reason, we define in this paper a sort of «conventional» minimum elapsed time (eight centuries) derived from: 1) the lack of earthquakes in the seismic catalogues which may be related to the mentioned faults, and 2) the hypotheses about the completeness of the historical information for the largest magnitude events reported in Stucchi and Albini (2000), indicating a low probability of lost historical information for destructive earthquakes in the period 1200 A.D.-present.

The investigated splay of the Mt. Vettore Fault is sealed by a colluvial unit ( 2 in fig. $5 a, b)$. The age of 1600-1510 years BP gives little information on the deposition age of this unit which, due to the colluvial origin, may have occurred many centuries after the reported date. As mentioned in the section dedicated to the stratigraphy of trench 1 , the presence of this colluvial unit over a wide area of the alluvial fan suggests that colluviation was not a depositional phase of a mere local importance. Significant colluviation following the reported date can probably be related to the 
climatic change which occurred during the 6th-7th century A.D. This means that a paleoseismologically inferred minimum elapsed time of 1300-1500 years can be defined.

\subsection{Recurrence intervals}

Radiocarbon dates permit hypotheses about the time span between the defined displacement events. However, available chronological constraints do not define very narrow time intervals of event occurrence.

First of all, in the case of the Mt. Vettore Fault the event E3 probably represents more than one episode of surface faulting. As for E2 and E1, we have no data to hypothesise that the two events are consecutive. Moreover, the upper chronological limit of E2 coincides with the lower chronological limit of E1 (41553965 years BP); therefore, the minimum time span between these two events would be zero. The maximum time span can be evaluated by first defining the uppermost chronological limit of E1. Based on the discussion in the previous section, this limit may be the 6th-7th century A.D. This chronology should be compared with the lower chronological limit of E2 (5940 years BP). Therefore, the maximum time span between E2 and E1 is 4690-4490 years, representing the maximum recurrence interval for surface faulting events along the Mt. Vettore Fault.

The recurrence interval of the Laga Mts. Fault is even less defined than that of the Mt. Vettore Fault, since we only have evidence for two events, both after $8320-8150$ years BP $(1 \sigma)$. These events are probably consecutive (i.e. no events are lacking in the investigated trench between E2 and E1) since unit 10 is a colluvium deposited in a wide open fissure formed during E2, while E1 was responsible for the displacement of the same colluvial unit.

As reported in the previous section, the upper chronological limit for E1 is 1200 A.D. The possibility that E1 occurred on 1200 A.D. and E2 occurred at 8320-8150 years BP gives a maximum time span between the two events of 7570 years.
In short, assuming that the investigated fault segments are representative of the entire fault zone, paleoseismological data may define time intervals not longer than 4690 years and not longer than 7570 years for the Mt. Vettore and Laga Mts. faults, respectively.

\subsection{Expected magnitude}

Hypotheses on the magnitude of the earthquakes which may originate along the investigated faults can be derived from the surficial fault length, by using the equation linking the Surface Rupture Length (SRL) with the moment magnitude (Wells and Coppersmith, 1994). We consider, indeed, that the length of the fault surficial expression (along which geomorphic evidence of recent activity can be detected) is comparable to the SRL, as the mentioned surficial expression results from the repetition of earthquakes which caused surface faulting.

Starting from this assumption we mapped the studied faults through the observation of aerial photographs and subsequent investigations in the field. Therefore, we were able to precisely estimate the fault surficial expression which resulted from cumulated episodes of surface faulting. The estimated length of the fault surficial expressions for the Mt. Vettore and Laga Mts. is 18 and $20 \mathrm{~km}$, respectively. Based on the equations linking the rupture length with the magnitude (Wells and Coppersmith, 1994), the expected magnitude for the mentioned faults is 6.5 and 6.6 , respectively.

\section{Conclusions}

Previous works on the Central Apennine active tectonics showed that two parallel sets of NW-SE trending active normal faults affect this portion of peninsular Italy. A comparison between the active faulting framework and the spatial distribution of the strong historical earthquakes (as derived from the available Italian catalogues) plus paleoseismological data indicated that the faults of the westernmost set activated during historical times. In contrast, no strong 
earthquakes $(M \geq 6.5)$ occurred in the areas where the faults of the easternmost set are located. The lack of historical earthquakes which may be related to this set defines a silent state for the eastern faults which, based on considerations about the completeness of the catalogue for the largest magnitude events, lasted for at least eight centuries.

Considering the historically silent behaviour, paleoseismological analyses were performed along two adjacent faults (Mt. Vettore and Laga Mts. faults) of the eastern set, in order: 1) to corroborate the hypotheses of recent activity previously derived from geomorphological investigations, and 2) to define quantitative parameters describing the fault behaviour.

As for point (1), the trenches made across the three mentioned faults showed the occurrence of repeated Holocene displacement events, thus confirming previous geomorphologically inferred hypotheses.

As for point (2), results of the paleoseismological analyses can be summarised as follows:

1) Number of events: three events were identified along the Mt. Vettore Fault, occurring between 4155-3965 years BP and the 6th-7th century A.D. (E1), between 5940-5890/5795-5780 years BP and 4155-3965 years BP (E2), and between 18000-12000 years BP and 59405890/5795-5780 years BP (E3) respectively; two events have been identified along the Laga Mts. Fault, both occurred after $8320-8150$ years BP.

2) Slip rate: the minimum vertical slip rates available for the Mt. Vettore Fault are 0.11-0.36 $\mathrm{mm} / \mathrm{yr}$ (paleoseismologically inferred) and 0.36$0.62 \mathrm{~mm} / \mathrm{yr}$ (geomorphologically inferred), while for the Laga Mts. Fault the minimum rate is $0.12 \mathrm{~mm} / \mathrm{yr}$ (paleoseismologically inferred) and the geomorphologically inferred vertical slip rate (based on the displacement of Late Pleistocene landforms) is $0.7-0.9 \mathrm{~mm} / \mathrm{yr}$.

3) Recurrence interval: the time interval between subsequent events is not longer than 4690 and 7570 years for the Mt. Vettore and the Laga Mts. fault, respectively.

4) Minimum elapsed time: paleoseismological data defined an elapsed time of 1300-1500 years since the last Mt. Vettore Fault activation; for the Laga Mts. Fault paleoseismological data on the elapsed time are sparser, due to the lack of reliably datable units sealing the investigated faults; for this reason the elapsed time was fixed in eight centuries, on the basis of the available historical data showing no evidence of earthquakes which may be related to the investigated faults and on considerations about the completeness of the seismic catalogues for the largest magnitude earthquakes.

5) Maximum expected magnitude: based on the length of the fault surficial expressions, and by means of the equations linking the surficial rupture length with the moment magnitude, the investigated faults may cause earthquakes with M 6.5 (Mt. Vettore) and 6.6 (Laga Mts.).

Considering the silent behaviour of the faults during at least the past eight centuries and the related high level of seismic hazard which may be associated to them, we believe that future research should focus on the production of damage scenarios related to the activation of the investigated faults. Although the faults affect high mountainous regions, villages with 5000-10000 inhabitants are located in the hangingwall areas and at distance not larger than $15 \mathrm{~km}$ from the surficial expressions of the investigated structures.

\section{Acknowledgements}

P. Messina (CNR, Istituto di Ricerca sulla Tettonica Recente, Roma) and R. Basili (Istituto Nazionale di Geofisica e Vulcanologia, Roma) participated in the analysis of the trench excavated across the Laga Mts. Fault. We are grateful to C. Giraudi for the discussions on the chronological framework of the Late Pleistocene-Holocene continental stratigraphy of the Central Apennines. One of the two anonymous referees suggested modifications which improved the paper.

\section{REFERENCES}

Barchi, M., F. Galadini, G. Lavecchia, P. Messina, A.M. Michetti, L. Peruzza, A. Pizzi, E. Tondi and E. ViTTORI (Editors) (2000): Sintesi delle conoscenze sulle faglie attive in Italia Centrale: parametrizzazione ai fini della caratterizzazione della peri- 
colosità sismica, GNDT, Gruppo Nazionale per la Difesa dai Terremoti, spec. publ., Roma, pp. 62.

BlumetTI, A.M., F. Dramis and A.M. MicheTtI (1993): Fault-generated mountain fronts in the Central Apennines (Central Italy): geomorphological features and seismotectonic implications, Earth Surf. Proc. and Land., 18, 203-223.

Boschi, E., G. Ferrari, P. Gasperini, E. Guidoboni, G. SMriglio and G. VAlEnsise (Editors) (1995): Catalogo dei Forti Terremoti in Italia dal 461 a.C. al 1980 (ING, Roma - SGA, Bologna), vol. 1, pp. 974

Boschi, E., E. Guidoboni, G. Ferrari, G. VAlensise and P. GASPERINI (Editors) (1997): Catalogo dei Forti Terremoti in Italia dal 461 a.C. al 1990 (ING, Roma SGA, Bologna), vol. 2, pp. 644.

Boschi, E., E. Guidoboni, G. Ferrari, D. Mariotti, G VALENSISE and P. GASPERINI (Editors) (2000): Catalogue of strong Italian earthquakes from 461 B.C. to 1997, Ann. Geofis., 43 (4), 609-868.

CAlamita, F. and A. Pizzi (1992): Tettonica quaternaria nella dorsale appenninica umbro-marchigiana e bacini intrappenninici associati, Studi Geol. Cam., 1 (spec. vol.), 17-25.

Calamita, F. and A. Pizzi (1994): Recent and active extensional tectonics in the Southern Umbro-Marchean Apennines (Central Italy), Mem. Soc. Geol. It., 48, 541-548.

Camassi, R. and M. Stucchi (1997): NT4.1, a Parametric Catalogue of Damaging Earthquakes in the Italian Area (Release NT4.1.1), http://emidius.mi.ingv.it/NT/ CONSNT.html.

Castelli, V., F. Galadini, P. Galli, D. Molin and M. STUCCHI (2002): Caratteristiche sismogenetiche della sorgente della Laga e relazione con il terremoto del 1639, in 21th National Congress of the Gruppo Nazionale di Geofisica della Terra Solida, Rome, November 19-21, 2002, abstract volume, 13-16.

Cello, G., S. Mazzoli, E. Tondi and E. Turco (1997): Active tectonics in the Central Apennines and possible implications for seismic hazard analysis in peninsular Italy, Tectonophysics, 272, 43-68.

Coltorti, M. and P. FARABollini (1995): Quaternary evolution of the Castelluccio di Norcia Basin, Il Quaternario, 8, 149-166.

D'Addezio, G., E. Masana and D. Pantosti (2001): The Holocene paleoseismicity of the AremognaCinque Miglia Fault (Central Italy), J. Seismol., 5, 181-205.

DrAMIS, F. (1983): Morfogenesi di versante nel Pleistocene superiore in Italia: i depositi detritici stratificati, Geogr. Fis. Din. Quat., 6, 180-182.

FrezzotTi, M. and C. Giraudi (1989): Evoluzione geologica tardo-pleistocenica ed olocenica del Piano di Aremogna (Roccaraso-Abruzzo): implicazioni climatiche e tettoniche, Mem. Soc Geol. It , 42, 5-19.

FrezzotTi, M. and C. Giraudi (1990a): Sedimenti eolici tardopleistocenici ed olocenici nell'Appennino centrale, Mem. Soc. Geol. It., 45, 883-886.

Frezzotti, M. and C. Giraudi (1990b): Late Glacial and Holocene aeolian deposits and geomorphological features near Roccaraso (Abruzzo, Central Italy), Quat. Int., 5, 89-95.

FrezZotTI, M. and C. GiRAudi (1992): Evoluzione geologica tardo-pleistocenica ed olocenica del conoide comp- lesso di Valle Majelama (Massiccio del Velino, Abruzzo), Il Quaternario, 5, 33-50.

FrezzoTTI, M and B. NARCISI (1989): Identificazione di un andosuolo, possibile livello guida per la cronostratigrafia olocenica dell'Appennino centrale, Mem. Soc. Geol. It., 42, 351-358.

Frezzotti, M. and B. NARCisI (1996): Late Quaternary tephra-derived paleosols in Central Italy's carbonate Apennine Range: stratigraphical and paleoclimatological implications, Ouat. Int., 34-36, 147-153.

Galadini, F. and P. Galli (1999): The Holocene paleoearthquakes on the 1915 Avezzano earthquake faults (Central Italy): implications for active tectonics in Central Apennines, Tectonophysics, 308, 143-170.

Galadini, F. and P. Galli (2000): Active tectonics in the Central Apennines (Italy) - input data for seismic hazard assessment, Nat. Hazards, 22, 225-270.

Galadini, F. and P. Messina (2001): Plio-Quaternary changes of the normal fault architecture in the Central Apennines (Italy), Geod. Acta, 14, 321-344.

Galadini, F., C. Meletti and E. VitToRi (2001): Major active faults in Italy: available surficial data, Geol. en Mijn. (Netherlands Journal of Geosciences), 80, 95-118.

Ghisetti, F. and L. Vezzani (2000): Modalità di riattivazione, circolazione dei fluidi e rottura sismica di alcune delle principali faglie normali nelle zone esterne dell'Appennino centrale, in Le Ricerche del GNDT nel Campo della Pericolosità Sismica (19961999), edited by F. Galadini, C. Meletti and A. ReBEZ (GNDT, Gruppo Nazionale per la Difesa dai Terremoti, Roma) 193-202.

GIRAUDI, C. (1994): Elementi di geologia del Quaternario della Piana di Campo Imperatore (Gran Sasso d'Italia), Atti Tic. Sc. Terra, spec. ser., 2, 137-143.

GIRAUDI, C. (1995): Sedimenti eolici, variazioni climatiche ed influenza antropica: considerazioni su alcune piane intermontane dell'Appennino abruzzese, Il Ouaternario, 8, 211-216.

GiRAudi, C. (1996): L'impronta del «Younger Dryas» degli «Heinrich Events» nell'evoluzione climatica e ambientale dell'Italia centrale, Il Quaternario, 9, 533-540.

GIRAUDI, C. (1998a): Late Pleistocene and Holocene lake level variations in Fucino Lake (Abruzzo, Central Italy) inferred from geological, archaeological and historical data, in ESF Workshop Palaeohydrology as Reflected in Lake-Level Changes as Climatic Evidence for Holocene Times, Paläoklimaforschung, 25, 1-17.

GIRAUDI, C. (1998b): I laghi effimeri tardopleistocenici e olocenici di Campo Imperatore e del Massiccio del Gran Sasso d'Italia (Abruzzo - Italia centrale), Il Quaternario, 11, 217-225.

GIRAUDI, C. (2000): Le oscillazioni oloceniche del ghiacciaio del Calderone, Gran Sasso d'Italia (Abruzzo Italia), Il Quaternario, 13, 31-36.

GIRAUDI, C.: Le oscillazioni del ghiacciaio del Calderone (Gran Sasso d'Italia, Abruzzo - Italia centrale) e le variazioni climatiche degli ultimi 3000 anni, Il Quaternario (in press).

Giraudi, C. and M. FrezzotTI (1995): Paleoseismicity in the Gran Sasso Massif (Abruzzo, Central Italy), Quat. Int., 25, 81-93.

Giraudi, C. and M. FrezzotTi (1997): Late Pleistocene 
glacial events in the Central Apennines, Italy, Quat. Res., 48, 280-290.

MagRi, G. and D. Molin (1984): Il terremoto del dicembre 1456 nell'Appennino centro-meridionale. ENEA Report RT/AMB, 8 (83), pp. 180.

Molin, D., F. Galadini, P. Galli, L. MucCi and A. Rossi (1999): Sismicità della zona del Fucino. in 13 Gennaio 1915, il Terremoto nella Marsica, edited by S. Castenetto and F. Galadini (Servizio Sismico Nazionale e CNR Istituto di Ricerca sulla Tettonica Recente, Roma), 249-271.

Monachesi, G. and M. StUCCHI (1998): DOM 4.1 an Intensity Database of Damaging Earthquakes in the Italian Area, http://emidius.mi.ingv.it/DOM/home.html.

Orombelli, G. and S.C. Porter (1982): Late Holocene fluctuations of Brenva glacier, Geogr. Fis. Dinam. Ouat., 5, 13-37.

Pantosti, D., G. D’Addezio and F.R. Cinti (1996): Paleoseismicity of the Ovindoli-Pezza Fault, Central Apennines, Italy: a history including a large, previously unrecorded earthquake in the Middle Ages (860-1300 A.D.), J. Geophys. Res., 101, 5937-5959.

Roberts, G.P., A.M. MichetTi, P. Cowie, N.C. Morewood and I. PAPANIKOLAU (2002): Fault slip-rate variations during crustal-scale strain localisation, Central Italy, Geophys. Res. Lett., 29 (8), 10.1029/ 2001GLO013529.

Strumia, G. (1997): Oscillazioni glaciali precedenti la piccola età glaciale documentate da un suolo sepolto in una morena del Ghiacciao del Lys, Il Quaternario, 10, 153-158.

Stucchi, M. and P. Albini (2000): Quanti terremoti distruttivi abbiamo perso nell'ultimo millennio? Spunti per la definizione di un approccio storico alla valutazione della completezza. in Le Ricerche del GNDT nel Campo della Pericolosità Sismica (19961999), edited by F. Galadini, C. Meletti and A. REBEZ, (GNDT, Gruppo Nazionale per la Difesa dai Terremoti, Roma), 333-343.

Stuiver, M., P.J. Reimer, E. Bard, J.W. Beck, G.S. Burr, K.A. Hughen, B. Kromer, G. McCormac, J. VAN DER Plicht and M. SPURK (1998): INTCAL98 Radiocarbon Age Calibration, 24000-0 cal BP, $R a$ diocarbon, 40, 1041-1084.

Valensise, G. and D. PAntosti (editors) (2001): Database of potential sources for earthquakes larger than M 5.5 in Italy, version 2.0, Ann. Geofis., 44 (suppl. to n. 4), 797-964.

Wells, D. L., and K.J. COPPERSMith (1994): New empirical relationships among magnitude, rupture length, rupture width, rupture area, and surface displacement, Seismol. Soc. Am. Bull., 84, 974-1002.

Working Group CPTI (1999): Catalogo Parametrico dei Terremoti Italiani (ING, GNDT, SGA SSN, Bologna), pp. 92. 